\title{
Racial Identity, School Racial Climate, and School Intrinsic Motivation Among African American Youth: The Importance of Person-Context Congruence
}

\author{
Christy M. Byrd and Tabbye Chavous \\ University of Michigan
}

\begin{abstract}
Researchers have been concerned with whether strong racial identification promotes or inhibits achievement motivation among African American youth, but current literatures have paid little attention to the role of youths' contexts. In this study, we outline a racial identity - context congruence framework that predicts positive benefits of a strong, positive racial identity when the context is congruent with youths' beliefs. To test this framework, we examined school racial climate as a moderator in the relationships of three racial identity variables (centrality, private regard, and public regard) with intrinsic motivation for attending school in a sample of 11th graders. Overall, results support the congruence perspective and also demonstrate how feelings of belonging at school mediate the relationship between racial identity-racial climate congruence and school intrinsic motivation.
\end{abstract}

Over the past two decades, research and popular discourse have taken up the question of whether strong racial group identification inhibits or promotes achievement motivation among African American adolescents (e.g., Chavous et al., 2003; Graham \& Hudley, 2005). However, within this work, scant attention has been paid to contextual variation in the roles and functions of racial identity, including how racial identity relates to youths' connections with the school context itself. Consequently, often we are left with the presumption that racial identity should function similarly across youth and contexts. In this study, we considered youths' school settings, specifically the school racial climates, examining how the congruence between youth's racial identity beliefs and school racial climate related to their intrinsic achievement motivation for school, that is, the extent youth link attending school to personally meaningful goals and values. Our focus on racial identity-racial climate congruence draws on ecological theory (e.g., Rappaport, 1977) and organizational theory (e.g., Chrobot-Mason \& Thomas, 2002) emphasizing the relevance of person-environment fit, that is, the match between characteristics of the person and characteristics of the environment. Furthermore, we drew on various achievement motivation theories highlighting the importance of affiliation and belongingness (e.g., Deci, Vallerand, Pelletier, \& Ryan, 1991) to consider whether feelings of belonging at school mediated the association between congruence in beliefs and climate perceptions and intrinsic motivation.

\footnotetext{
Requests for reprints should be sent to Christy M. Byrd, 1406 School of Education Bldg., 610 S. University Ave, Ann Arbor, MI 48109. E-mail: cmbyrd@umich.edu
}

\section{AFRICAN AMERICAN RACIAL IDENTITY AND ACADEMIC ACHIEVEMENT}

Current literatures on African American achievement highlight ways racial identity can impact academic motivation and engagement (e.g., Chavous et al., 2003; Oyserman, Harrison, \& Bybee, 2001). A common theme across these literatures is the acknowledgement of historical barriers to African American educational success and the proposition that youth who strongly identify with their racial group will respond to those barriers by developing connections between the self and the academic domain that have implications for their schooling outcomes. There are varying perspectives, however, on the nature of youths' responses to racial barriers. Smalls, White, Chavous, and Sellers (2007) describe a "racial-identity-as-promotive" perspective that emphasizes historical values African Americans have placed on education for attaining upward group mobility and equality. This perspective posits that strongly identified youth will usually connect their racial identity to more positive academic values and, subsequently, show higher motivation and achievement. Additionally, such youth would be more likely to maintain positive academic-self concept and persist academically when experiencing racial stigma or barriers relative to youth with a less strong and positive racial group identification. Other theoretical frameworks highlight academic risks associated with stronger identification with a racial group that has experienced and continues to experience barriers and stigma. For instance, Fordham and Ogbu's

(C) 2011 The Authors

Journal of Research on Adolescence (C) 2011 Society for Research on Adolescence DOI: $10.1111 /$ j.1532-7795.2011.00743.x 
(1986) cultural ecological framework emphasizes how Black youth may come to define their culture in opposition to mainstream systems that have excluded their group-including education - and, subsequently, come to view their personal identities as incompatible with proschool orientations. Alternatively, youths' identification with a group stigmatized or devalued in the academic domain may disidentify, or disconnect their self-concept from that domain, to protect their self-concept (e.g., Crocker \& Major, 1989; Steele, 1997).

In our study, we conceptualized youths' racial identity beliefs as their cognitions around the importance and meaning of racial group membership, drawing on the Multidimensional Model of Racial Identity (MMRI) (Sellers, Smith, Shelton, Rowley, \& Chavous, 1998). We examined two MMRI dimensions, racial centrality and racial regard. Racial centrality is the importance of race to individuals' overall identity. The regard component includes: private regard, which taps into group pride or the degree individuals feel positively or negatively about African Americans and being African American; and public regard, individuals' views of how society evaluates African Americans. Our focus on these dimensions allowed us to consider youths' level of racial group identification (centrality) as distinct from their personal affective beliefs about their racial group (private regard) and their beliefs about how others view their racial group (public regard). Each dimension may have unique implications for how youth respond to race-related cues and experiences in their social contexts (Sellers, Rowley, Chavous, Shelton, \& Smith, 1997); thus, the dimensions are particularly appropriate for our focus on individual differences in associations of youths' school racial climate perceptions with their school motivation.

Generally, more empirical research supports direct benefits of high racial centrality and private regard on adolescent academic attitudes and performance (e.g., Chavous et al., 2003; Chavous, Rivas, Smalls, Griffin, \& Cogburn, 2008; O'Connor, 1999; Oyserman, Gant, \& Ager, 1995; Oyserman et al., 2001; Spencer, Noll, Stoltzfus, \& Harpalani, 2001). Also, higher centrality and lower public regard each have been shown to buffer negative effects of racial stigma (e.g., discrimination) on academic and psychological outcomes (e.g., Chavous et al., 2008; Oyserman et al., 2001; Sellers, Caldwell, SchmeelkCone, \& Zimmerman, 2003; Sellers, CopelandLinder, Martin, \& Lewis, 2006; Wong, Eccles, \& Sameroff, 2003). However, a few studies have found negative associations of measures of racial identity indicating a stronger, positive racial identification with academic outcomes among Black youth (e.g., Harper \& Tuckman, 2006; Worrell, 2007). The findings raise the possibility of variation in ways racial identity beliefs influence youths' academic adjustment.

\section{RACIAL IDENTITY-CONTEXT CONGRUENCE APPROACH}

Considering youths' academic contexts can help reconcile mixed findings in the literature and contribute to understanding of different mechanisms linking racial identity to academic outcomes. As such, we focus on congruence between youths' racial identity beliefs and the meanings associated with race in their environments. The aforementioned scholarship provides important insights on mechanisms linking youths' beliefs about their racial group membership in society to self-belief systems they develop around the academic domain (e.g., academic self-concept, attitudes about the utility of education). Our congruence approach adds to this work by considering the nature of youths' connections with their proximal school contexts and draws from theoretical perspectives emphasizing the role of person-environment fit in successful adaptation (e.g., Rappaport, 1977). Specifically, we examined school racial climate, that is, school settings' norms and values around race and interracial interactions (Chavous, 2005; Green, Adams, \& Turner, 1988). Students' day-to-day school racial climate experiences represent one manifestation of African Americans' racial group status in the broader society. As such, youth with particular racial identity beliefs about the importance and meaning of their group membership may respond to their school racial climate in different manners.

A congruence perspective takes up several theoretical and empirical gaps in previous racial identity literatures. First, it addresses explicitly the role of students' academic contexts in shaping their motivational orientations. Previous research suggests African American adolescents experiencing school racial climates characterized by frequent intergroup contact, fair treatment, and respect for all races show more positive achievement (Green et al., 1988) and motivation (Brand, Felner, Shim, Seitsinger, \& Dumas, 2003; Ryan \& Patrick, 2001). Additionally, the racial climate is viewed as particularly influential for African American students because of the salience of race in their lives (Booker, 2006; Mattison \& Aber, 2007). However, school climate research generally has not addressed within-racial group differences in responses to school climate, nor how students' own 
race beliefs relate to their perceptions of and responses to their climates.

Second, current achievement motivation frameworks highlight ways racial identity relates to African American youths' adaptations in the context of societal or interpersonal racial stigma. A congruence approach considers how racial identity might function in both positive and negative racial contexts. Recent research provides evidence of contextual variation in the associations between racial identity and adolescent achievement outcomes. Byrd and Chavous (2009) found a positive relationship between private regard (racial pride) and grade achievement among African American adolescents from economically disadvantaged neighborhoods but a negative relationship among those from more advantaged neighborhoods. The authors speculated that the function of private regard was different in these two settings. That is, private regard may have represented a personal asset in disadvantaged neighborhoods and a reactive response to devaluation in advantaged neighborhoods. Because disadvantaged neighborhoods were more predominantly Black, race was likely salient in more positive ways; thus, racial pride would be more consistent with community values. In contrast, in more advantaged and predominantly White neighborhoods, race was likely salient in more negative ways; thus, strong racial pride may have made youth vulnerable to lower achievement. Similarly, Sellers and Shelton (2003) found that more negative beliefs about how society regards African Americans (lower public regard) attenuated negative effects of personal racial discrimination on African American youths' psychological adjustment. The authors posited that although experiencing racial stigma was a psychological risk factor, those lower in public regard had worldviews that included the possibility of group bias. Thus, they would be better able to understand and cope with the discrimination such that it less negatively affected psychological well-being. In contrast, youth with higher public regard likely were less prepared for negative experiences contradicting their beliefs about how others view their group (Sellers et al., 2006; Sellers \& Shelton, 2003). Taken together, the studies suggest the value of considering interactions between youths' racial identities and contextual characteristics.

One mechanism through which racial identitycontext congruence influences school intrinsic motivation is through youths' sense of belonging at school. Motivation scholarship indicates individuals' engagement in a setting depends, in part, on the environment satisfying individuals' needs for relat- edness and belonging (e.g., Deci et al., 1991). School climate literatures suggest that being in a hostile school racial climate can reduce Black students' sense of connection to school, even if they value the outcomes of education (Booker, 2006). Finally, organizational theory asserts that individuals feel less personally connected to settings where there is incongruence between individual and perceived setting values (Chrobot-Mason \& Thomas, 2002), and this incongruence has implications for belonging, satisfaction, and perseverance within the setting (Chatman, 1991). Chrobot-Mason and Thomas (2002) discuss racial identity as an individual difference variable that can directly interact with organizations' approaches to diversity. The authors posit, for instance, that African American employees who see their race as very important to them may be most comfortable and successful in organizations that value racial differences and have positive intergroup relations. In contrast, they may feel alienated in organizations stressing adherence to a single cultural norm and ignoring the importance of race. Similarly, considering congruence between youths' racial identity beliefs and school norms around race may be vital in untangling the effects of racial identity on academic motivation. Specifically, we argue that school settings more consistent with and supportive of youths' positive connections to their racial group should result in youth feeling stronger connections to the school context and, subsequently, higher school intrinsic motivation.

\section{THE CURRENT STUDY}

The current study focused on adolescents' racial identity beliefs, school racial climate perceptions, and personal (intrinsic) motivation for attending school. We were interested in direct associations of racial identity and school racial climate with motivation. Based on prior scholarship, we expected that higher racial centrality and private regard and more positive school racial climate perceptions generally would relate to higher school intrinsic motivation.

Also, we were interested in associations between racial identity and motivation for youth whose racial identity beliefs were congruent and incongruent with their perceived school racial climate. Research indicates direct positive effects of centrality on achievement motivation outcomes and its protective role among individuals experiencing racial stigma (e.g., Chavous et al., 2008). Thus, while we expected that youth reporting higher centrality would report higher school motivation when experiencing negative racial climates relative to youth lower in 

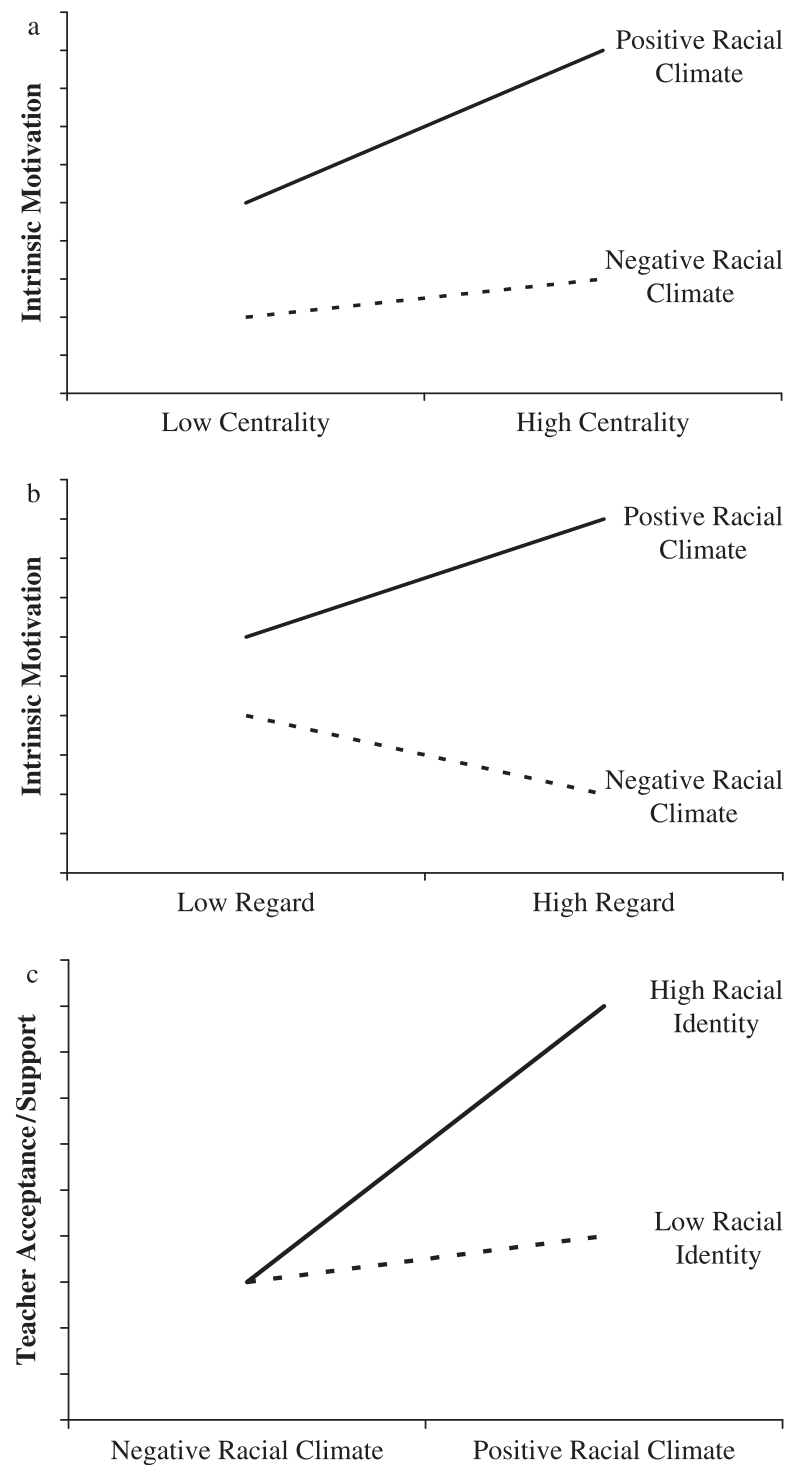

FIGURE 1 (a) Hypothesized interaction of centrality and school racial climate as a predictor of school intrinsic motivation. (b) Hypothesized interactions of private and public regard with school racial climate as a predictor of school intrinsic motivation. (c) Hypothesized interactions of school racial climate with racial identity variables (centrality, private regard, and public regard) as predictors of school belonging and acceptance.

centrality, we expected that positive racial climates - those in which race is salient in a positive way-would enhance the positive association of centrality with motivation (see Figure 1a). Research has indicated positive direct effects of private regard on motivation outcomes but is more equivocal with regard to its protective effects in relation to experienced racial stigma (e.g., Sellers et al., 2006). School climates congruent with high private regard beliefs would be those that support positive views of
African Americans, for example, where African Americans have similar status to other racial groups and positive interactions with other groups. Such climates would serve to affirm youths' positive group feelings and, thus, enhance the positive effects of high private regard on school intrinsic motivation. In contrast, we expected a negative association between private regard and school intrinsic motivation among students experiencing more negative, less affirming racial climates (see Figure $1 \mathrm{~b}$ ). We expected a similar pattern for public regard but for different conceptual reasons. Youth with lower public regard perceive society as devaluing their group and, therefore, may be more protected from the negative motivational consequences of a negative racial climate than youth with higher public regard, because the climate is congruent with their expectations (e.g., Sellers et al., 2006). Compared to youth with lower public regard, youth with higher public regard would report higher school intrinsic motivation when perceiving climates with positive norms and values around race (see Figure $1 \mathrm{~b}$ ).

Finally, we expected youths' feelings of belonging at school (perceived support and acceptance) to mediate the association between racial identityracial climate congruence and intrinsic motivation for school (see Figure 1c).

\section{METHOD}

\section{Participants}

Participants were 359 African American 11th graders (53\% male) in the longitudinal Maryland Adolescent Development in Context Study (MADICS). Students attended public schools in neighborhoods with diverse demographic characteristics (including rural, suburban, and urban settings, and representing a range of income and socioeconomic status levels). The median income level for the sample youths' family households was US $\$ 45,000$-US $\$ 49,000$; over $50 \%$ of sample adolescents' primary caregivers graduated high school and $40 \%$ completed some college. (For detailed study characteristics, see http:// www.rcgd.isr.umich.edu/pgc/home.htm.) Only participants with complete data for all current study variables were included $(n=263)$; youth with missing data did not differ on most variables, but youth who were excluded had significantly lower family education and income, were older, and reported lower private regard. Participants and their parents were given face-to-face and self-administered interviews. 


\section{Measures}

Measures of intrinsic motivation, school racial climate, and school belonging were created by MADICS staff. School intrinsic motivation was measured with three items assessing the extent youth reported enjoying their classes, liking what they were learning, and feeling smart as important reasons they went to school $(\alpha=.84)$. Participants responded on a scale of $1=$ not an important reason to $7=a$ very important reason.

Racial identity. Youth completed a shortened version of the Multidimensional Inventory of Black Identity (Sellers et al., 1997). Three centrality items measured the extent race was an important part of youths' self-concept, for example, "Being Black is an important reflection of who I am" $(\alpha=.73)$. The sixitem private regard subscale assessed the degree youth felt positively or negatively about their race, for example, "I am happy that I am Black" ( $\alpha=.77)$. Finally, public regard was assessed with two items indicating the degree youth felt society valued African Americans (e.g., "Others think that Black people are unworthy"; $r=.41)$. All items were on a scale of $1=$ strongly disagree to 5 = strongly agree.

School racial climate. School racial climate scales were created based on conceptual considerations and confirmed by exploratory and confirmatory factor analysis. Peer racial climate consisted of four items indicating how often students of different races spent time together (e.g., "How often do students of different races sit together in the cafeteria?") on a scale of $1=$ never to $5=$ very often and respect among students of different races on a scale of $1=$ none to $5=$ all $(\alpha=.73)$. Teacher $/$ staff racial climate was measured with two items assessing how many teachers showed equal respect for students of different races on a scale of $1=$ none to $5=$ all, and frequency of racial tension between staff and students on a scale of $1=$ almost never to $5=$ almost always $(r=.37)$.

School belonging. Deci et al. (1991) define belonging in a setting in terms of relatedness and "secure and satisfying connections with others" (p. 327). In this study, school belonging was assessed by measures of support and acceptance from peers and teachers at school. Peer support was a two-item measure indicating how often youth depended on other students for help with problems at school and schoolwork on a scale of $1=$ almost never to $5=$ almost always $(r=.43)$. Teacher support and acceptance was measured with three items assessing on a 1-5 scale how happy youth were with their relationships with their teachers, whether teachers accepted them as they were, and how often they had arguments with their teachers. Higher scores indicated more support and acceptance $(\alpha=.59)$.

Student background and control variables. Background variables included 11th grade GPA from school records, youth-reported gender, and a standardized composite measure of family socioeconomic status representing family income and highest education attained in the home (reported by parents or primary caregivers when youth were in eighth grade). Also, we included youths' reported personal peer and teacher discrimination over the last school year using scales from previous research including the present study sample (Chavous et al., 2008; Wong et al., 2003). Peer discrimination included three items asking youth how often youth they got into fights, were picked on, or were excluded from teams or activities because of their race $(\alpha=.87)$. Teacher discrimination included five items assessing youths' perceptions unfair treatment because of their race, for example being disciplined more harshly $(\alpha=.89)$. Youth responded on a scale of $1=$ never to $5=$ almost every day.

\section{RESULTS}

\section{Means and Correlations}

Descriptive statistics and correlations are reported in Table 1. Generally, youth reported high or moderately high private regard $(M=4.35, S D=0.55)$, and centrality $(M=3.75, S D=0.79)$, while public regard scores were around the scale midpoint $(M=2.97$, $S D=0.85)$. Peer racial climate was around the scale midpoint $(M=3.16, S D=0.72)$, and teacher racial climate was generally positive $(M=4.07, S D=0.78)$. Average intrinsic motivation was above the scale midpoint $(M=4.59, S D=1.46)$.

Of the racial identity variables, only private regard was correlated with intrinsic motivation, showing a small, significant association $(r=.15$, $p<.01)$. Teacher/staff racial climate scores were positively correlated with intrinsic motivation scores $(r=.21, p<.005)$, and intrinsic motivation showed a small, positive association with youths' grades $(r=.22, p<.005)$. Also, correlations indicated reports of peer racial climate and teacher/staff racial climate were significantly associated with, but conceptually distinct from, reports of personal racial discrimination from peers and teachers $(r=-.22, p<.001$, and $r=-.55, p<.001$, respectively). 
TABLE 1

Means, Standard Deviations, and Correlations for Sample $(N=359)$

\begin{tabular}{|c|c|c|c|c|c|c|c|c|c|c|c|c|c|}
\hline & Mean & $S D$ & 1 & 2 & 3 & 4 & 5 & 6 & 7 & 8 & 9 & 10 & 11 \\
\hline 1. GPA & 2.79 & 0.71 & & & & & & & & & & & \\
\hline 2. SES & 0.07 & 0.84 & $.15^{* * *}$ & & & & & & & & & & \\
\hline 3. Year of birth & a & & $.15^{* * *}$ & $.14^{* *}$ & & & & & & & & & \\
\hline 4. Gender $(1=$ Female $)$ & 0.47 & 0.50 & $.23^{* * *}$ & -.08 & $.08^{+}$ & & & & & & & & \\
\hline 5. Teacher discrimination & 1.43 & 0.70 & $-.22^{* * *}$ & -.08 & -.03 & $-.30 * * *$ & & & & & & & \\
\hline 6. Peer discrimination & 1.53 & 0.71 & $-.17^{* * *}$ & -.07 & -.07 & $-.21 * * *$ & $.65^{* * *}$ & & & & & & \\
\hline 7. Private regard & 4.35 & 0.55 & $.23^{* * *}$ & $.18^{* * *}$ & .07 & .00 & $-.03 * * *$ & $-.30 * * *$ & & & & & \\
\hline 8. Public regard & 2.97 & 0.85 & $.10^{+}$ & $.12^{*}$ & .05 & .04 & $.17^{* * *}$ & $-.11^{*}$ & .05 & & & & \\
\hline 9. Centrality & 3.75 & 0.79 & .04 & $.10^{+}$ & .06 & $-.09^{+}$ & .00 & -.04 & $.49^{* * *}$ & $-.10^{+}$ & & & \\
\hline 10. Peer racial climate & 3.16 & 0.72 & $.11^{*}$ & -.06 & .06 & $.14^{* *}$ & $-.14^{* *}$ & $-.22 * * *$ & .06 & $.14^{* *}$ & .04 & & \\
\hline 11. Teacher racial climate & 4.07 & 0.78 & $.16^{* * *}$ & -.02 & .03 & $.19^{* * *}$ & $-.55^{* * *}$ & $-.71^{* * *}$ & $.15^{* *}$ & $.15^{* * *}$ & -.05 & $.24^{* * *}$ & \\
\hline 12. Intrinsic motivation & 4.59 & 1.46 & $.22 * * *$ & -.02 & -.08 & .08 & $-.13^{*}$ & $-.13^{*}$ & $.15^{* *}$ & $.09^{+}$ & .03 & $.10^{+}$ & $.21^{* * *}$ \\
\hline
\end{tabular}

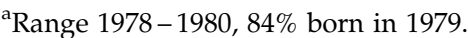

${ }^{+} p<.10 ;{ }^{*} p<.05 ;{ }^{* *} p<.01 ;{ }^{* * *} p<.005$.

\section{Racial Identity and Racial Identity-Context Congruence as a Predictor of Intrinsic Motivation}

Racial identity and racial climate variables were examined as predictors of school intrinsic motivation using hierarchical ordinary least squares regressions. In the first step, we entered control variables (year of birth, gender, SES, and GPA), peer and teacher discrimination, racial identity, and school racial climate variables. The six interaction terms for racial identity and racial climate were entered in the second step. The racial identity and racial climate variables were centered around their means to reduce multicollinearity (Aiken, West, \& Reno, 1991). A summary of findings is presented in Table 2, Steps 1-2.

The final model explained $17 \%$ of the variance in the dependent variable. It was notable that peer racial discrimination was not associated with intrinsic motivation, and neither was teacher racial discrimination after entering interactions of racial climate and racial identity in Step 2. Positive teacher/staff racial climate was associated with higher intrinsic motivation in Step $1(B=.41, p<.01)$ and Step 2 $(B=.34, p<.05)$.

Neither racial centrality nor public regard was associated with school intrinsic motivation. Private regard showed a marginal association $(B=.29, p<$ .10) qualified by two significant interactions with school racial climate. To examine the interactions, we plotted intrinsic motivation scores for private regard and racial climate scores at one standard deviation above and below their means, in a procedure outlined by Aiken et al. (1991). Figure 2 shows the interaction between private regard and peer racial climate $(B=.57, p<.01)$. Among youth experiencing positive peer racial climates, private regard was positively and strongly related to school intrinsic motivation. For youth reporting negative peer racial climates, private regard showed a small but significant and negative relationship with intrinsic motivation. Figure 3 illustrates the interaction between private regard and teacher/staff racial climate $(B=.43, p<.05)$. Among youth experiencing positive teacher/staff racial climates, private regard was strongly and positively related to intrinsic motivation for school. However, for youth reporting negative teacher/staff climates, private regard was unrelated to motivation. In sum, youths' intrinsic motivation for school differed for those whose private regard beliefs were more congruent or less congruent with their perceived school racial climate.

\section{School Belonging as a Mediator of the Relationship of Racial Climate With Intrinsic Motivation}

A main hypothesis of our study is that a match between students' strong, positive racial identity beliefs and their perceived school climate promotes intrinsic motivation for school, because higher congruence should increase sense of belonging to the school context. Accordingly, we tested whether youth reports of peer and teacher support and acceptance would explain the relationship between racial climate and intrinsic motivation, and whether this meditational relationship varied for youth with differing racial identity beliefs. 
TABLE 2

Hierarchical Regression of Racial Identity and School Racial Climate Predicting Intrinsic Motivation

\begin{tabular}{|c|c|c|c|c|c|c|}
\hline \multirow{3}{*}{$\begin{array}{l}\text { Model } F \text { (df regression, df residual) } \\
R^{2} \text { change }\end{array}$} & \multicolumn{2}{|c|}{ Step 1} & \multicolumn{2}{|c|}{ Step 2} & \multicolumn{2}{|c|}{ Step 3} \\
\hline & \multicolumn{2}{|c|}{$\begin{array}{c}3.87(11,346)^{* * *} \\
0.10^{*}\end{array}$} & \multicolumn{2}{|c|}{$\begin{array}{c}3.67(17,340)^{* * * *} \\
0.05^{* *}\end{array}$} & \multicolumn{2}{|c|}{$\begin{array}{c}4.83(19,338)^{* * *} \\
0.05^{* * *}\end{array}$} \\
\hline & $B$ & $S E$ & $B$ & $S E$ & $B$ & $S E$ \\
\hline Intercept & $35.04^{*}$ & 14.47 & $38.47^{* *}$ & 14.30 & $42.54^{* *}$ & 13.88 \\
\hline Year of birth & $-0.40^{*}$ & 0.18 & $-0.45^{*}$ & 0.18 & $-0.52^{* *}$ & 0.18 \\
\hline Gender & 0.05 & 0.16 & 0.03 & 0.16 & 0.01 & 0.16 \\
\hline SES & -0.07 & 0.09 & -0.05 & 0.09 & -0.11 & 0.09 \\
\hline GPA & $0.38^{* * *}$ & 0.11 & $0.39^{* * *}$ & 0.11 & $0.25^{*}$ & 0.11 \\
\hline Teacher discrimination & $0.05^{+}$ & 0.15 & -0.01 & 0.15 & 0.08 & 0.14 \\
\hline Peer discrimination & 0.16 & 0.17 & 0.07 & 0.17 & 0.09 & 0.17 \\
\hline Private regard & 0.31 & 0.17 & $0.29^{+}$ & 0.17 & 0.22 & 0.17 \\
\hline Public regard & 0.09 & 0.09 & 0.05 & 0.09 & 0.02 & 0.09 \\
\hline Centrality & -0.01 & 0.11 & 0.03 & 0.11 & 0.07 & 0.11 \\
\hline Peer racial climate & 0.07 & 0.11 & 0.11 & 0.11 & 0.12 & 0.11 \\
\hline Teacher racial climate & $0.41^{* *}$ & 0.14 & $0.34^{*}$ & 0.14 & 0.23 & 0.14 \\
\hline Priv regard $\times$ peer climate & & & $0.57^{* *}$ & 0.21 & $0.43^{*}$ & 0.21 \\
\hline Priv regard $\times$ teacher climate & & & $0.43^{*}$ & 0.21 & 0.32 & 0.20 \\
\hline Pub regard $\times$ peer climate & & & 0.08 & 0.12 & 0.08 & 0.12 \\
\hline Pub regard $\times$ teacher climate & & & -0.11 & 0.10 & -0.14 & 0.10 \\
\hline Cent $\times$ peer climate & & & -0.04 & 0.14 & 0.03 & 0.14 \\
\hline Cent $\times$ teacher climate & & & -0.18 & 0.15 & -0.21 & 0.14 \\
\hline Teacher acceptance/support & & & & & $0.55^{* * *}$ & 0.12 \\
\hline
\end{tabular}

${ }^{+} p<.10 ;{ }^{*} p<.05 ; * * p<.01 ; * * * p<.001$

We took a mediated moderation approach (Muller, Judd, \& Yzerbyt, 2005) and found that peer support did not mediate the relationship between climate and motivation; however, teacher support and acceptance did. The results for the mediation analyses are reported in Table 2, Step 3 and in Table 3. There was an overall mediating effect of teacher acceptance and support in the relationship between teacher/staff racial climate and motivation

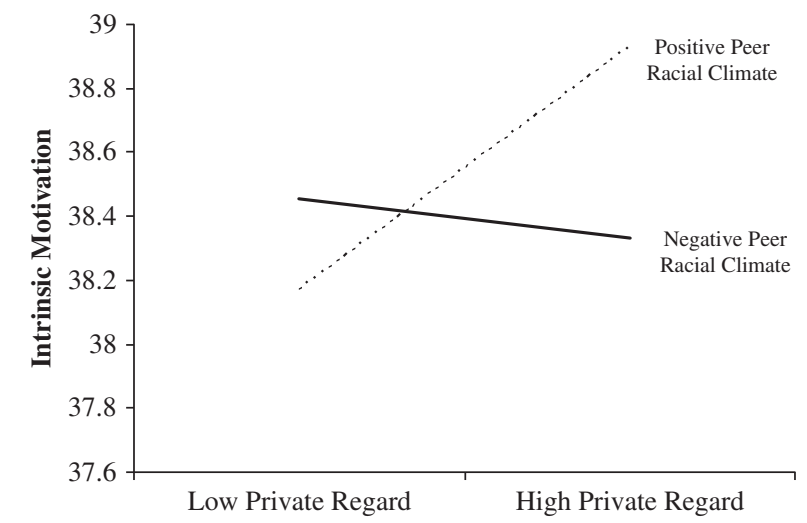

FIGURE 2 Private regard and peer racial climate as predictors of school intrinsic motivation.
$\left(B_{\text {original }}=.34, p<.05 ; B_{\text {controlling for acceptance }}=.23, n s\right)$. Additionally, there was a trend such that the effect of teacher racial climate on the mediator, teacher support and acceptance, depended on the level of racial identity $(B=.18, p<.10)$. A graph of this interaction appears in Figure 4 . For youth with higher private regard, there was a stronger relationship between teacher/staff racial climate and teacher acceptance and support - that is, the associ-

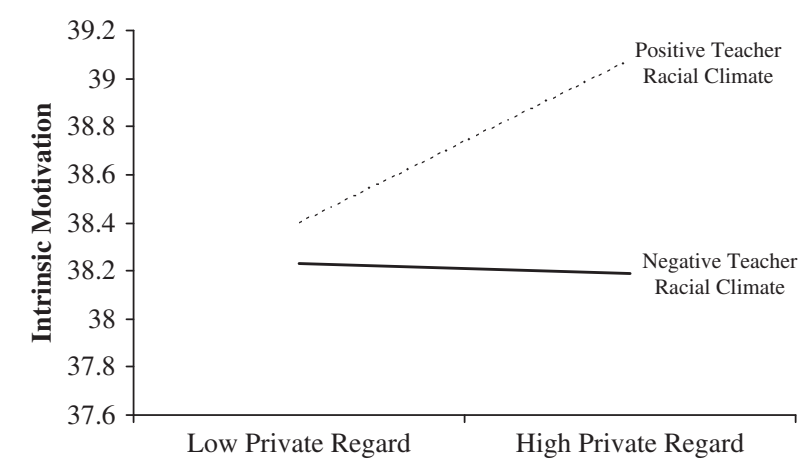

FIGURE 3 Private regard and teacher/staff racial climate as predictors of school intrinsic motivation. 
TABLE 3

Mediational Analyses Condition 2: School Racial Climate Predicting Peer and Teacher Acceptance/Support

\begin{tabular}{|c|c|c|c|c|c|c|}
\hline \multirow{4}{*}{$\begin{array}{l}\text { Model F (df) } \\
R^{2}\end{array}$} & \multirow{2}{*}{\multicolumn{2}{|c|}{ Outcome: Peer Support }} & \multicolumn{4}{|c|}{ Outcome: Teacher Acceptance/Support } \\
\hline & & & \multicolumn{2}{|c|}{ Step 1} & \multicolumn{2}{|c|}{ Step 2} \\
\hline & \multicolumn{2}{|c|}{$0.93(11,345)$} & \multicolumn{2}{|c|}{$18.75(11,346)^{* * *}$} & \multicolumn{2}{|c|}{$12.43(17,340)^{* * *}$} \\
\hline & $B$ & $S E$ & $B$ & $S E$ & $B$ & $S E$ \\
\hline Intercept & -8.73 & 9.36 & -9.54 & 6.63 & -7.40 & 6.55 \\
\hline Year of birth & 0.14 & 0.12 & $0.16^{+}$ & 0.08 & 0.13 & 0.08 \\
\hline Gender & 0.02 & 0.10 & 0.05 & 0.07 & 0.04 & 0.07 \\
\hline SES & -0.03 & 0.06 & $0.09^{*}$ & 0.04 & $0.11^{*}$ & 0.04 \\
\hline GPA & 0.08 & 0.07 & $0.24^{* * *}$ & 0.05 & $0.26^{* * *}$ & 0.05 \\
\hline Teacher discrimination & 0.13 & 0.10 & $-0.14^{*}$ & 0.07 & $-0.16^{*}$ & 0.07 \\
\hline Peer discrimination & -0.10 & 0.11 & 0.00 & 0.08 & -0.02 & 0.08 \\
\hline Private regard & 0.16 & 0.11 & $0.14^{+}$ & 0.08 & 0.13 & 0.08 \\
\hline Public regard & -0.06 & 0.06 & $0.09^{*}$ & 0.04 & 0.06 & 0.04 \\
\hline Centrality & -0.06 & 0.07 & -0.06 & 0.05 & -0.07 & 0.05 \\
\hline Peer racial climate & 0.05 & 0.07 & -0.01 & 0.05 & -0.02 & 0.05 \\
\hline Teacher racial climate & 0.01 & 0.09 & $0.21^{* * *}$ & 0.06 & $0.20^{* *}$ & 0.07 \\
\hline Private regard $\times$ peer climate & & & & & $0.25^{*}$ & 0.10 \\
\hline Private regard $\times$ teacher climate & & & & & $0.18^{+}$ & 0.10 \\
\hline Public regard $\times$ peer climate & & & & & 0.02 & 0.06 \\
\hline Public regard $\times$ teacher climate & & & & & 0.06 & 0.05 \\
\hline Centrality $\times$ peer climate & & & & & $-0.13^{*}$ & 0.06 \\
\hline Centrality $\times$ teacher climate & & & & & 0.05 & 0.07 \\
\hline
\end{tabular}

${ }^{+} p<.10 ;{ }^{*} p<.05 ;{ }^{* *} p<.01 ;{ }^{* * *} p<.005$.

ation of teacher/staff racial climate with students' perceived acceptance and support from teachers was stronger than the association between the two variables for youth lower in private regard. Thus, conditions of mediated moderation were met-the moderating effect of teacher/staff racial climate in the association between private regard and intrinsic motivation was explained by teacher acceptance and support.

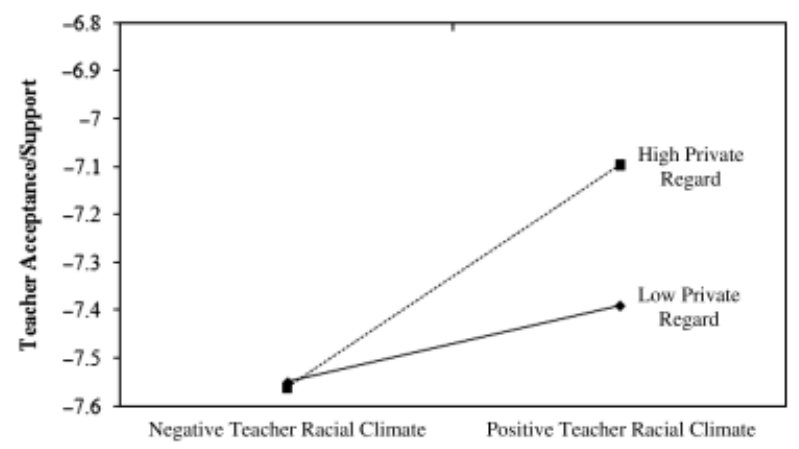

FIGURE 4 Peer racial climate and private regard as predictors of teacher support/acceptance.

\section{DISCUSSION}

The current study examined whether adolescents' racial identity beliefs related to their intrinsic motivation for attending school and whether these relationships varied for youth experiencing negative or positive racial climates at school. In our examination, we integrated prior scholarship with a person-environment fit approach by considering congruence between adolescents' racial identity beliefs and their school racial climates. While most prior research on racial identity and achievement focuses on processes linking racial identity to academic self-concept and/or abstract educational values, we considered connections between youths' personal identities and their proximal school contexts.

Results generally supported prior school climate research (e.g., Brand et al., 2003) in that youth perceiving positive attitudes around race from teachers and staff reported higher school intrinsic motivation. Counter to prior findings, racial identity beliefs showed little direct association with school intrinsic motivation, but racial identity-context congruence did relate to motivation. Consistent with our expectations that positive racial climates would enhance 
positive effects of high private regard on motivation, youth with higher private regard reported more intrinsic motivation when experiencing environments where they perceived more positive intergroup contact and all races as valued. Among youth experiencing environments characterized by racial exclusion, inequity, and tension among peers, however, having higher private regard beliefs was weakly but still significantly related to lower motivation. The results held even when accounting for youths' reported personal experiences with school-based racial discrimination. As suggested by Byrd and Chavous (2009), youth with higher private regard in settings where race is salient in ways that signal Blacks' lower group status may react by disengaging from those settings. Overall, findings suggest ways youths' motivational orientations are a function of youths' personal characteristics and their experienced environment, beyond individual effects of identity beliefs or perceived climate.

Surprisingly, we did not find direct or interactive associations of racial centrality or public regard with school racial climate in predicting our intrinsic motivation variable. Results speak to the importance of examining different achievement motivation outcomes. While high racial centrality may influence positive values about the importance and utility of education and high academic self-concept and performance (e.g., Chavous et al., 2003, 2008), youths' intrinsic motivation for engaging in the school context itself represents a different motivational construct. Our findings suggest the merits of examining adolescents' motivation related to their school environments as distinctive from their academic selfconcept beliefs and abstract educational values. It is possible, for instance, that some youth value the abstract goals and purposes of education but feel disconnected from a particular school setting that devalues them personally (e.g., Booker, 2006). Future work might consider how racial identity and school contextual attributes relate to different motivational variables and the consequences of each for achievement. Similarly, higher racial centrality and lower public regard have been shown to buffer negative effects of personal racial discrimination on psychological and academic outcomes (Caldwell, Chavous, Barnett, Kohn-Wood, \& Zimmerman, 2003; Chavous et al., 2008; Sellers et al., 2003, 2006; Wong et al., 2003). Those beliefs, however, may not help youth maintain their personal connection with their school when they experience group devaluation in this context. Consistent with this finding, Chavous et al. (2003) noted that for high school adolescents with higher race centrality and lower public regard, the importance of education for the future was most predictive of later educational attainment, but the personal relevance and enjoyment of what youth were learning in school was not predictive of attainment among these youth.

The lack of significant associations for public regard also speaks to the importance of distinguishing youths' perceptions of how race functions in society more broadly from their perceptions of race norms within their proximal contexts. Research investigating stigmatized identities tends to assume negative stereotypes about African Americans in society infiltrate all contexts in which youth develop (Steele, 1997). Furthermore, these perspectives assume that, even when African Americans are devalued in a setting, youth perceive that devaluing and that it affects their beliefs and behavior. However, some youth contexts may actually support positive representations of African Americans, and experiencing these settings as valuing their group may be more influential on intrinsic motivation within these settings than more abstract societal views. In fact, a more positive school climate may be especially beneficial for youth who perceive racial stigma at the societal level, because the school may function as an oasis of positive support in an unsupportive society. More research needs to be conducted to examine how public regard influences and is influenced by youths' experiences of their proximal settings, including school-based experiences.

Finally, it may be that private regard was more strongly related to school intrinsic motivation relative to other identity variables because both tap into personally relevant affective experiences; that is, private regard deals with the individuals' personal feelings about the group's worth, and intrinsic motivation entails attachment of personal values and goals to school-including personal enjoyment of school. Thus, positive personal feelings about one's group may be of unique relevance in predicting youths' school-related affect.

\section{School Belonging as a Mediating Factor}

Results indicated that school belonging was important in predicting school intrinsic motivation and in explaining associations of racial identity-context congruence with motivation. School climates defined by inclusion and equity related to African American students' sense of belonging to and connectedness with their settings (e.g., Booker, 2006). Furthermore, the relationship was stronger for youth with higher private regard. Findings suggest experiencing a school racial climate consistent with youths' positive 
racial group beliefs is important to their development of positive connections to their school (teacher relationships in which youth feel accepted and supported), which, in turn, can lead youth to link attending school to personally meaningful values. For youth with lower private regard, perceiving a climate encouraging positive group representations and intergroup interactions may be less influential on their development of positive connections to school. For these youth, other school characteristics and experiences may play a stronger role in facilitating positive relationships with teachers and peers. In sum, our overall findings demonstrate the utility of considering person-context congruence when studying how adolescents' racial identity beliefs relate to achievement motivation.

\section{Limitations and Considerations}

We measured intrinsic motivation for attending school but did not assess intrinsic motivation for learning more generally. In addition, other motivational attributes not assessed likely contribute to youth achievement. The racial-identity-as-promotive perspective (Smalls et al., 2007) describes how recognition of historical barriers prompts African Americans to achieve; therefore youth who are externally motivated by these historical barriers may be successful regardless of their intrinsic motivation around school. Valuing outcomes of schooling (i.e., occupational success, financial stability, giving back to one's family or community) may be just important as a form of integrated motivation, in which the activity is conducted because it is of personal value and an expression of one's identity (Deci et al., 1991). Our study did not speak to these types of motivation. Nevertheless, intrinsic motivation for school is uniquely important because personal enjoyment can produce a lifelong commitment to learning that may be more impervious to changes in values such as becoming aware of contextual discrimination (which can decrease the expected value of education). Furthermore, individuals' feeling personally connected to and valued in their environments is a basic human need and relates to more engagement within those environments, which is more likely to lead to persistence and success (Deci \& Ryan, 2008).

Other study considerations include use of subscales with moderate reliability indicators (although this is less concerning given the interitem correlations and small number of scale items for those measures). Also, peer and teacher/staff racial climate scales assessed relations among different groups but did not refer specifically to treatment of African Americans, which may have provided stronger support for our hypotheses. Because the study relied on secondary data analysis, the racial climate scales were constructed based on available items using existing racial climate frameworks as a theoretical guide. Thus, future research might employ other established climate scales. We note that youths' motivation scores in our sample represented the higher end of the response range, although findings suggest variation within that range was still meaningful. Similarly, although other studies report similarly high private regard scores as our final sample, within our study youth excluded due to incomplete data on study variables had lower average private regard than those with complete data. This may have constricted our ability to test fully the range of the relationships that exist. Finally, our racial identity variables were not available in prior study waves, which limits our ability to draw causal conclusions. Thus, future work could test the current study questions using longitudinal methodologies.

\section{CONCLUSIONS}

For African American adolescents with strong racial pride, being in schools with a fair and respectful racial climate appears to be most adaptive for satisfying youths' need for belonging and encouraging intrinsic motivation. This paper contributes to the racial identity literature by complicating the discourse over whether particular racial identity beliefs are adaptive or maladaptive. This study shows that similar reported beliefs can have different consequences in relation to adaptation within a setting depending on youths' perceptions of setting norms. Finally, the implications of this work for educators are that African American youth vary in their beliefs about race and that, for some youth, increasing their motivation may have nothing to do with altering youths' beliefs about themselves but about promoting a school environment that is supportive of and congruent with their positive group beliefs. Similarly, interventions aimed at changing African American youths' educational values may be less effective relative to efforts to create more inclusive school contexts that promote positive connections with youths' day-to-day learning environments. Thus, our findings suggest school racial climate as a potentially important point of intervention for promoting adolescent academic engagement. 


\section{REFERENCES}

Aiken, L. S., West, S. G., \& Reno, R. R. (1991). Multiple regression: Testing and interpreting interactions. London, $\mathrm{UK}$ : Sage Publications.

Booker, K. C. (2006). School belonging and the African American adolescent: What do we know and where should we go? The High School Journal, 89, 1-7.

Brand, S., Felner, R., Shim, M., Seitsinger, A., \& Dumas, T. (2003). Middle school improvement and reform: Development and validation of a school-level assessment of climate, cultural pluralism, and school safety. Journal of Educational Psychology, 95, 570-588.

Byrd, C. M., \& Chavous, T. M. (2009). Racial identity and academic achievement in the neighborhood context: A multilevel analysis. Journal of Youth and Adolescence, 38, $544-559$.

Caldwell, C. H., Chavous, T. M., Barnett, T. E., Kohn-Wood, L. P., \& Zimmerman, M. A. (2003). Social determinants of experiences with violence among adolescents: Unpacking the role of race in violence. Phylon, 50, 87-113.

Chatman, J. A. (1991). Matching people and organizations: Selection and socialization in public accounting firms. Administrative Science Quarterly, 36, 459-485.

Chavous, T. M. (2005). An intergroup contact-theory framework for evaluating racial climate on predominantly White college campuses. American Journal of Community Psychology, 36, 239-257.

Chavous, T. M., Bernat, D. H., Schmeelk-Cone, K., Caldwell, C. H., Kohn-Wood, L., \& Zimmerman, M. A. (2003). Racial identity and academic attainment among African American adolescents. Child Development, 74, 1076-1090.

Chavous, T. M., Rivas, D., Smalls, C., Griffin, T., \& Cogburn, C. (2008). Gender matters, too: The influences of school racial discrimination and racial identity on academic engagement outcomes among African American adolescents. Developmental Psychology, 44, 637-654.

Chrobot-Mason, D., \& Thomas, K. M. (2002). Minority employees in majority organizations: The intersection of individual and organizational racial identity in the workplace. Human Resource Development Review, 1, 323 344.

Crocker, J., \& Major, B. (1989). Social stigma and selfesteem: The self-protective properties of stigma. Psychological Review, 96, 608-630.

Deci, E. L., \& Ryan, R. M. (2008). Facilitating optimal motivation and psychological well-being across life's domains. Canadian Psychology, 49, 14-23.

Deci, E. L., Vallerand, R. J., Pelletier, L. G., \& Ryan, R. M. (1991). Motivation and education: The self-determination perspective. Educational Psychologist, 26, 325-346.

Fordham, S., \& Ogbu, J. U. (1986). Black students school success: Coping with the "burden of 'acting white'." The Urban Review, 18, 176-206.

Graham, S., \& Hudley, C. (2005). Race and ethnicity in the study of motivation and competence. In A. J. Elliot \& C. S. Dweck (Eds.), Handbook of competence and motivation (pp. 392-413). New York, NY: Guilford Press.
Green, C. W., Adams, A. M., \& Turner, C. W. (1988). Development and validation of the school interracial climate scale. American Journal of Community Psychology, 16, $241-259$.

Harper, B. E., \& Tuckman, B. W. (2006). Racial identity beliefs and academic achievement: Does being Black hold students back? Sociology of Education, 9, 381-403.

Mattison, E., \& Aber, M. S. (2007). Closing the achievement gap: The association of racial climate with achievement and behavioral outcomes. American Journal of Community Psychology, 40, 1-12.

Muller, D., Judd, C. M., \& Yzerbyt, V. Y. (2005). When moderation in mediated and mediation is moderated. Journal of Personality and Social Psychology, 89, $852-863$.

O'Connor, C. (1999). Race, class, and gender in America: Narratives of opportunity among low-income African American youth. Sociology of Education, 72, 137-157.

Oyserman, D., Gant, L., \& Ager, J. (1995). A socially contextualized model of African American identity: Possible selves and school persistence. Journal of Personality and Social Psychology, 69, 1216-1232.

Oyserman, D., Harrison, K., \& Bybee, D. (2001). Can racial identity be promotive of academic efficacy? International Journal of Behavioral Development, 25, 379-385.

Rappaport, J. (1977). Community psychology: Values, research, $\mathcal{E}$ action. New York, NY: Holt, Rinehart \& Winston.

Ryan, A. M., \& Patrick, H. (2001). The classroom social environment and changes in adolescents' motivation and engagement during middle school. American Educational Research Journal, 38, 437-460.

Sellers, R. M., Caldwell, C. H., Schmeelk-Cone, K. H., \& Zimmerman, M. A. (2003). Racial identity, racial discrimination, perceived stress, and psychological distress among African American young adults. Journal of Health and Social Behavior, 44, 302-317.

Sellers, R. M., Copeland-Linder, N., Martin, P. P., \& Lewis, R. L. (2006). Racial identity matters: The relationship between racial discrimination and psychological functioning in African American adolescents. Journal of Research on Adolescence, 16, 187-216.

Sellers, R. M., Rowley, S. A. J., Chavous, T. M., Shelton, J. N., \& Smith, M. A. (1997). Multidimensional inventory of Black identity: A preliminary investigation of reliability and construct validity. Journal of Personality and Social Psychology, 73, 805-815.

Sellers, R. M., \& Shelton, J. N. (2003). The role of racial identity in perceived racial discrimination. Journal of Personality and Social Psychology, 84, 1079-1092.

Sellers, R. M., Smith, M. A., Shelton, J. N., Rowley, S. A. J., \& Chavous, T. M. (1998). Multidimensional model of racial identity: A reconceptualization of African American racial identity. Personality and Social Psychology Review, 2, 18-39.

Smalls, C., White, R., Chavous, T., \& Sellers, R. (2007). Racial ideological beliefs and racial discrimination experiences as predictors of academic engagement among 
African American adolescents. Journal of Black Psychology, 33, 299-330.

Spencer, M. B., Noll, E., Stoltzfus, J., \& Harpalani, V. (2001). Identity and school adjustment: Revisiting the "acting white" assumption. Educational Psychologist, 36, 21-30.

Steele, C. M. (1997). A threat in the air: How stereotypes shape intellectual identity and performance. American Psychologist, 52, 613-629.
Wong, C. A., Eccles, J. S., \& Sameroff, A. (2003). The influence of ethnic discrimination and ethnic identification on African American adolescents' school and socioemotional adjustment. Journal of Personality, 71, 11971232.

Worrell, F. C. (2007). Ethnic identity, academic achievement, and global self-concept in four groups of academically talented adolescents. Gifted Child Quarterly, 51, 23-38. 